Bull. Chem. Soc. Ethiop. 2021, 35(2), 257-272.

(c) 2021 Chemical Society of Ethiopia and The Authors

ISSN 1011-3924

DOI: https://dx.doi.org/10.4314/bcse.v35i2.4

Printed in Ethiopia

Online ISSN 1726-801X

\title{
ASSESSMENT OF METALS CONTENT OF WIDELY USED TRADITIONAL TOOTHBRUSHES IN ADDIS ABABA, ETHIOPIA
}

\author{
Yared Fikadu Mulualem and Bhagwan Singh Chandravanshi* \\ Department of Chemistry, College of Natural and Computational Sciences, Addis Ababa \\ University, P.O. Box 1176, Addis Ababa, Ethiopia
}

(Received December 6, 2020; Revised August 26, 2021; Accepted August 29, 2021)

\begin{abstract}
Traditional toothbrushes are used by the vast majority of people who cannot afford to buy the commercial toothbrush and toothpaste. The traditional toothbrushes are generally obtained from any slim woody part of a toothbrush tree. The main purpose of this study was to determine selected metals $(\mathrm{Ca}, \mathrm{Fe}, \mathrm{Mg}, \mathrm{Al}, \mathrm{Cu}, \mathrm{Cr}$, $\mathrm{Ni}, \mathrm{Zn}, \mathrm{Mn}, \mathrm{Pb}$, and $\mathrm{Cd}$ ) in traditional toothbrushes obtained from three plants including Ligustrum vulgare $\mathrm{L}$., Phoenix reclinata and Olea africana, which are extensively used in Addis Ababa, Ethiopia, by using microwave plasma-atomic emission spectroscopy (MP-AES) after wet digestion. Recoveries of the metals in spiked samples varied from $90.4-107 \%$. The overall mean concentrations determined $(\mathrm{mg} / \mathrm{kg}$, dry weight) were in the ranges of $\mathrm{Ca}(4267-36514)>\mathrm{Fe}(131-318)>\mathrm{Al}(81.6-224)>\mathrm{Mg}(45.6-122)>\mathrm{Zn}(27.2-175)>\mathrm{Mn}(20.1-29)>\mathrm{Cu}(6.6-$ $20.3)>\mathrm{Cr}(6.7-8.9)>\mathrm{Ni}(2.6-7.9)$. Analysis of variance at 95\% indicated significant differences in the metals' contents of three toothbrushes. The results indicated that the selected traditional toothbrushes are good sources of essential metals and free from $\mathrm{Pb}$ and $\mathrm{Cd}$. Therefore, the investigated Ethiopian traditional toothbrushes are found to be safe for human use.
\end{abstract}

KEY WORDS: Metal contents, Traditional toothbrushes, Wild privet (Ligustrum vulgare), Wild date palm (Phoenix reclinata), African wild olive (Olea africana), Ethiopia

\section{INTRODUCTION}

Oral health is part of total health and essential to the quality of life. The World Health Organization puts oral diseases among the top five causes of burden in 'lost healthy years' worldwide [1]. The major cause of such oral diseases is due to dental caries which are mainly a result of poor hygiene. Moreover, systemic health may be affected as a result of problems in oral hygiene [2]. One of the important ways to decrease oral health problem is the use of toothbrush. The toothbrush is an oral hygiene instrument used to clean the teeth and gums that consists of a head of tightly clustered bristles mounted on a handle, which facilitates the cleansing of hard-toreach areas of the mouth. In the world people use two broad types of toothbrushes which are traditional and synthetic toothbrushes. Traditional toothbrushes are used by the vast majority of people who cannot afford to buy the commercial toothbrush and toothpaste. The traditional toothbrushes are important for the oral and dental hygiene of the users and hence may be useful in decreasing dental caries [3]. The traditional toothbrush is generally obtained from any slim woody part of the tree. Mostly it is harvested from branches although harvest from woody roots is also known. Long twig sections of 50 or $100 \mathrm{~cm}$ are cut and transported to the market before being cut to retail sizes. The thickness of these toothbrushes is dependent on the type of tree and the part of branch harvested while the length is more dependent on the retailer [4]. The World Health Organization has encouraged the use of chewing sticks (traditional toothbrushes) as an alternative source of oral hygiene in poor countries where many people cannot afford commercial dental products.

Although commercially made toothbrushes from leading international brands are available in Addis Ababa supermarkets and pharmacies, many people say they prefer the chewing sticks.

${ }^{*}$ Corresponding author. E-mail: bscv2006@yahoo.com

This work is licensed under the Creative Commons Attribution 4.0 International License 
It is better because it is natural. The present study is based on the three most widely used plants in Addis Ababa, Ethiopia. These are wild privet (Ligustrum vulgare), wild date palm (Phoenix reclinata) and African wild olive (Olea africana). L. vulgare also sometimes known as common privet is native to central and southern Europe, North Africa and southwestern Asia [5]. L. vulgare is cultivated in Ethiopia in different area specially urban areas in Harar, Bahir Dar, Addis Ababa, Hawasa, etc. for evergreen the campus compound (in the green field) and parks in addition to use as toothbrush.

$P$. reclinata the wild date palm is a species of flowering plant in the palm family native to tropical Africa, the Arabian Peninsula, Madagascar and the Comoro Islands [6]. P. reclinata is cultivated in Ethiopia in different area especially urban areas and hot regions like Amhara region, Bahir Dar, Finote Selam, Debre Markos, Addis Ababa, Hawasa, etc. for ever greening the road and compounds in addition to use as toothbrush.

The African wild olive, previously known as O. africana subspecies cuspidata is now regarded as $O$. europaea subspecies africana. The names depend on which taxonomy and nomenclature are followed. Its common name is African wild olive. The plant belongs to the family Oleaceae [7]. It is geographically distributed throughout the Southern Africa and Northwards through East Tropical Africa into Eritrea [8]. O. africana is cultivated in Ethiopia in all regions both rural and urban and especially in hot regions, for most of the time it is cultivated evergreen for traditional uses, e.g. for its smoke for coffee ceremony in addition to use as toothbrush. The $O$. europaea subspecies africana plant branches are used in traditional toothbrush as a substitute of synthetic plastic brush and paste used for oral health and prevention of dental.

Leaves of $L$. vulgare have been used for treatment of oropharyngeal inflammations or as an anti-rheumatic, diuretic, and hypotensive agents in folk medicine in southern Europe [9]. The $O$. europaea subspecies africana plant leaves are used in folk medicine as a remedy for eye infections, sore throat, urinary tract infections, kidney problems and backaches or headaches. It is also used as a hypotensive, emollient, febrifuge and styptic [10]. The leaves of the tree were reported to be potent for the treatment of malaria [11]. In vitro antioxidant activity of olive leaf extract (Olea europaea L.) and its protective effect on oxidative damage in human erythrocytes have been reported [12]. O. europaea has a number of traditional and contemporary uses in medicine. O. europaea is extensively used in traditional medicine for a wide range of ailments in various countries. Its bark, fruits, leaves, wood, seeds, and oil are used in different forms, alone or sometimes in combination with other herbs. The oil of the seed is taken orally as a laxative and also applied externally as a balm for inflammation [13]. Decoctions of dried leaves and fruit are used orally to treat diarrhea, respiratory and urinary tract infections, stomach and intestinal diseases, and as mouth cleanser [14]. Continuous application of olive oil is also useful to prevent hair loss. In East-Africa the infusion of the bark of the olive tree is taken for tapeworm infestation [15].

Although the World Health Organization has promoted the use of toothbrush sticks [16] and has encouraged further research of their efficacy, few studies have been undertaken on the potential antimicrobial properties of chewing sticks [17]. These traditional toothbrushes have high importance in removing parts of food left on the teeth, in addition to their antibacterial property. Synthetic toothpaste contain known metal content which are important for oral health, however, there exists no current studies which evaluate the metal content of traditional toothbrushes obtained from the plants. Because dietary habits are among the major concerns of human health, and are of increasing importance in almost all countries of essential nutrients are fundamental [18].

Most Ethiopian people use traditional toothbrush especially in Addis Ababa. Besides many essential metals required for human health some toxic metals may also present in toothbrushes from $L$. vulgare, $P$. reclinata, and $O$. africana. Since these plants take essential and nonessential metals from the soil and water to grow, the source of toxic metals may originate from 
polluted air, water and soils, or may also be naturally occurring. In the world especially in Ethiopia all traditional toothbrush users have no information about metal content in different types of traditional toothbrushes. Therefore, it is necessary to create awareness about the metal content of each traditional toothbrush in the world especially developing countries like Ethiopia.

The literature survey revealed that there are no studies on the content of heavy metals in the branch part of three plants namely $L$. vulgare, $P$. reclinata, and $O$. africana commonly used as traditional toothbrushes in Ethiopia. Therefore, this study is focused on the determination of eleven selected metals such as $\mathrm{Ca}, \mathrm{Mg}, \mathrm{Al}, \mathrm{Fe}, \mathrm{Cu}, \mathrm{Zn}, \mathrm{Mn}, \mathrm{Pb}, \mathrm{Cr}, \mathrm{Ni}$ and $\mathrm{Cd}$ in L. vulgare, $P$. reclinata, and $O$. africana by microwave plasma-atomic emission spectroscopy (MP-AES). The study aims to compare the levels of the identified metals in the three plants cultivated in three different areas in Addis Ababa to the concentration of each metal in other medicinal plants and commercial toothpastes reported in the literature.

\section{EXPERIMENTAL}

\section{Apparatus and equipments}

Chopping board (PTFE, China) and Teflon (PTFE, China) knife were used to cut the branch of selected plants and to reduce the size into small pieces. A drying oven (Griffin and George Ltd, Britain) was used to dry the plant samples. Mortar and pestle were used to ground the samples. Analytical balance (Larko, LA114, $110 \mathrm{~g} / 0.1 \mathrm{~g}$ ) with precision of $\pm 0.0001 \mathrm{~g}$ was used to weigh the samples. A $250 \mathrm{~mL}$ round bottomed flasks (24/29) fitted with reflux condensers were used in Kjeldahl apparatus hot plate to digest the dried and powdered samples. Borosilicate volumetric flasks $(50 \mathrm{~mL})$ were used during dilution of sample and preparation of metal standard solutions. Measuring cylinders (Duran, Germany), micro-pipettes (1-20 $\mu \mathrm{L}$ and 10-100 $\mu \mathrm{L}$, Pyrex, USA), were used during measuring different quantities of volumes of sample solution, acid reagents and metal standard solutions. Microwave plasma-atomic emission spectrometer (Agilent 4200 MP AES, USA) was used for the determination of the analyte metals (Al, $\mathrm{Ca}, \mathrm{Mg}, \mathrm{Cu}, \mathrm{Zn}, \mathrm{Mn}$, $\mathrm{Ni}, \mathrm{Fe}, \mathrm{Co}, \mathrm{Cr}, \mathrm{Pb}$ and $\mathrm{Cd}$ in the L. vulgare, O. africana and $P$. reclinata samples.

\section{Reagents and chemicals}

Reagents used in the analysis were all analytical grade. $\mathrm{HNO}_{3}(69.5 \%$ reagent grade, ACS, ISO, European Union) and $\mathrm{HClO}_{4}(70 \%$, Fine-Chem, Mumbai, India) were used for digestion of samples. Stock standard solutions containing $1000 \mathrm{mg} / \mathrm{L}$ of the metals $\mathrm{Al}, \mathrm{Ca}, \mathrm{Mg}, \mathrm{Cu}, \mathrm{Zn}, \mathrm{Mn}$, $\mathrm{Ni}, \mathrm{Fe}, \mathrm{Co}, \mathrm{Cr}, \mathrm{Pb}$ and $\mathrm{Cd}$ (Perkin Elmer, Boston, USA) were used for preparation of calibration standards and in the spiking experiments. Deionized water (chemically pure with conductivity $\leq$ $1.5 \mu \mathrm{s} / \mathrm{cm}$ ) was used for dilution of samples and standards.

\section{Description of the study area}

Addis Ababa is the capital city of Ethiopia. The area of Addis Ababa covers about $540 \mathrm{~km}^{2}$ of which $18 \mathrm{~km}^{2}$ are rural. Addis Ababa has a subtropical highland climate with precipitation varying considerably by the month. Addis Ababa is provided with an average $1089 \mathrm{~mm}$ of rainfall per year, or $90.8 \mathrm{~mm}$ per month (2009-2017). The city has a complex mix of highland climate zones, with temperature differences of up to $10{ }^{\circ} \mathrm{C}$, depending on elevation and prevailing wind patterns. The high elevation moderates temperatures year-round, and the city's position near the equator means that temperatures are very constant from month to month. As such as no month is above $22{ }^{\circ} \mathrm{C}$ in mean temperatures. The highest temperature on record was $30.6{ }^{\circ} \mathrm{C}$ on 26 February 2019 , while the lowest temperature on record was $0{ }^{\circ} \mathrm{C}$ recorded on multiple occasions. The three types of traditional toothbrushes were collected from three 
different parts of Addis Ababa, Ethiopia namely: Kotebe, Ferensay and Arat Kilo Addis Ababa University campus where the three plants are more cultivated in Addis Ababa. Kotebe is located in Yeka sub-city, Ferensay is located in Gulele sub-city, and Arat Kilo, Addis Ababa University campus is located in Arada sub-city. The location map of Addis Ababa showing the three subcities is shown in Figure 1.

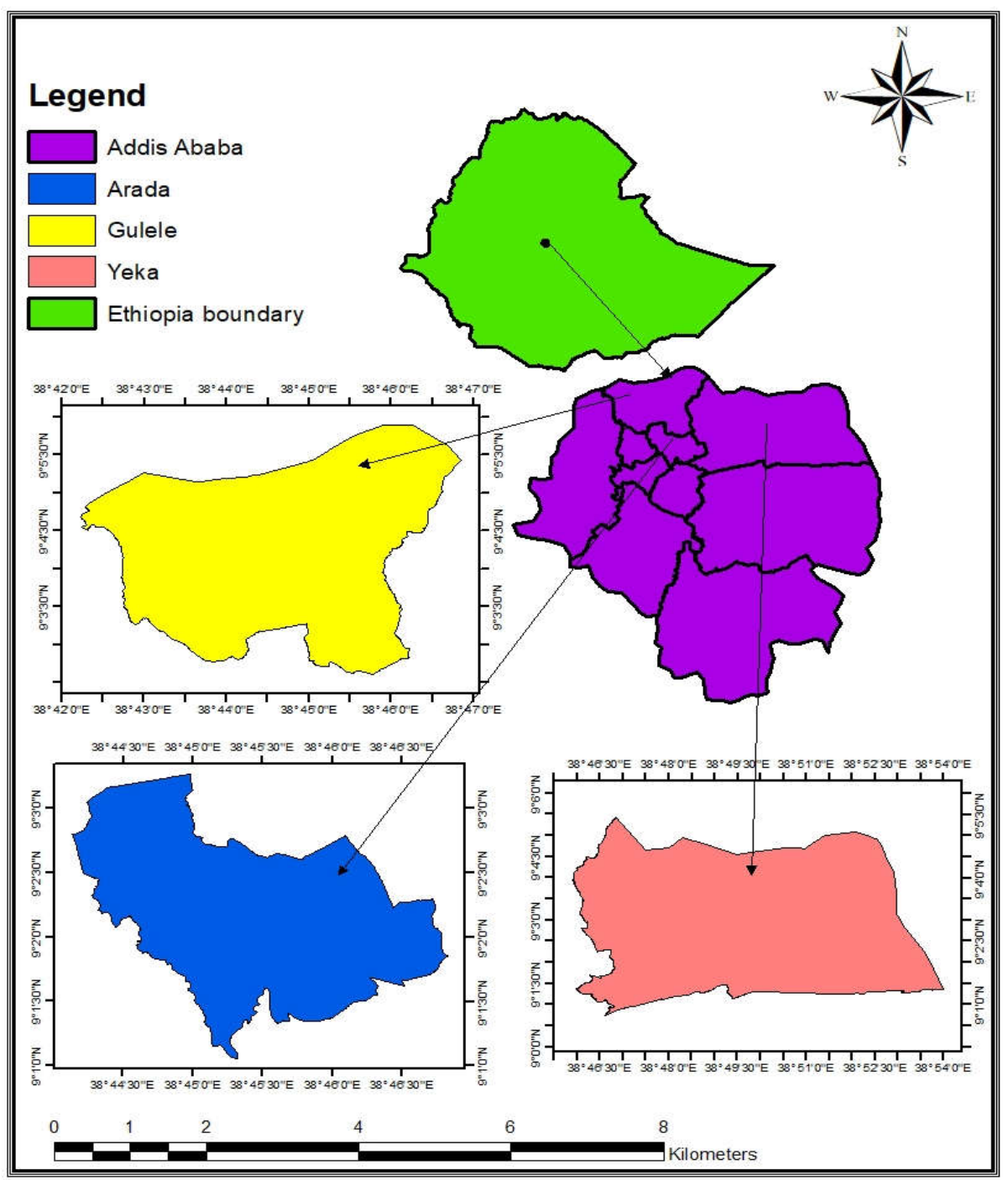

Figure 1. The location map of Addis Ababa showing the three sub-cities.

Optimization of the digestion procedure for selected traditional toothbrush samples

It is common practice in any scientific experiments in general and in analytical chemistry in particular that the optimum working conditions should be determined before carrying out any 
experimental activities for sample preparation before analysis [19]. The basic requirements for sample preparation for analysis are to establish an optimum condition for the digestion. The optimum condition in the wet digestion is the one which required minimum reagent volume consumption, minimum reflux time, clarity of digests, and ease of simplicity. In this study, to prepare a clear colorless sample solution for the analysis using MP-AES, $0.5 \mathrm{~g}$ of powdered and homogenized traditional toothbrush sample was weighed and transferred to $250 \mathrm{~mL}$ of a round bottom flask. To this, different volumes of nitric acid and perchloric acid at specified proportions ( $\mathrm{v} / \mathrm{v})$ were added and digested at different temperature and for different time (Table 1). During the optimization, the total volume was kept constant while studying the volume ratio of the two acids. Similarly, the volume ratio of the two acids was kept constant while varying the total volume. Different volumes of nitric and perchloric acids are commonly used for the decomposition of plant materials [20-26]. Therefore different volumes of nitric and perchloric acids were used for the decomposition of traditional toothbrushes in this study.

Table 1. Different conditions tested for optimization of digestion procedure for $0.5 \mathrm{~g}$ of $O$. africana, $L$. vulgare and $P$. reclinata.

\begin{tabular}{|c|c|c|c|c|c|c|}
\hline 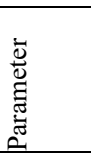 & Trial & Reagents used & $\begin{array}{c}\text { Reagent } \\
\text { volume ratio } \\
(\mathrm{mL})\end{array}$ & $\begin{array}{c}\text { Temperature } \\
\left({ }^{\circ} \mathrm{C}\right)\end{array}$ & $\begin{array}{c}\text { Digestion } \\
\text { time (h) }\end{array}$ & Observation \\
\hline \multicolumn{7}{|c|}{ O. africana } \\
\hline \multirow{6}{*}{ 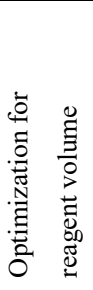 } & 1 & $\mathrm{HNO}_{3}: \mathrm{HClO}_{4}$ & $3: 3$ & 300 & $3: 00$ & Light yellow \\
\hline & 2 & $\mathrm{HNO}_{3}: \mathrm{HClO}_{4}$ & $4: 2$ & 300 & $3: 00$ & Deep yellow \\
\hline & 3 & $\mathrm{HNO}_{3}: \mathrm{HClO}_{4}$ & $3: 2$ & 300 & $3: 00$ & Yellow \\
\hline & 4 & $\mathrm{HNO}_{3}: \mathrm{HClO}_{4}$ & $4: 1^{*}$ & 300 & 3:00 & Clear and colorless \\
\hline & 5 & $\mathrm{HNO}_{3}: \mathrm{HClO}_{4}$ & $2: 2$ & 300 & $3: 00$ & Clear light yellow \\
\hline & 6 & $\mathrm{HNO}_{3}: \mathrm{HClO}_{4}$ & $3: 1$ & 300 & $3: 00$ & Deep yellow \\
\hline \multirow[t]{3}{*}{ రृ } & 1 & $\mathrm{HNO}_{3}: \mathrm{HClO}_{4}$ & $4: 1$ & 150 & $3: 00$ & Deep yellow \\
\hline & 2 & $\mathrm{HNO}_{3}: \mathrm{HClO}_{4}$ & $4: 1$ & 180 & $3: 00$ & Clear light yellow \\
\hline & 3 & $\mathrm{HNO}_{3}: \mathrm{HClO}_{4}$ & $4: 1$ & 210 & $3: 00$ & Clear light yellow \\
\hline \multirow{3}{*}{ 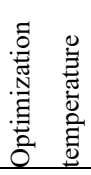 } & 4 & $\mathrm{HNO}_{3}: \mathrm{HClO}_{4}$ & $4: 1$ & 240 & $3: 00$ & Clear and light yellow \\
\hline & 5 & $\mathrm{HNO}_{3}: \mathrm{HClO}_{4}$ & $4: 1$ & $270^{*}$ & 3:00 & Clear and colorless \\
\hline & 6 & $\mathrm{HNO}_{3}: \mathrm{HClO}_{4}$ & $4: 1$ & 300 & $3: 00$ & Clear and colorless \\
\hline \multirow{6}{*}{ 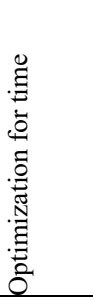 } & 1 & $\mathrm{HNO}_{3}: \mathrm{HClO}_{4}$ & $4: 1$ & 270 & $1 ; 45$ & Deep yellow \\
\hline & 2 & $\mathrm{HNO}_{3}: \mathrm{HClO}_{4}$ & $4: 1$ & 270 & $2: 00$ & Clear and light yellow \\
\hline & 3 & $\mathrm{HNO}_{3}: \mathrm{HClO}_{4}$ & $4: 1$ & 270 & $2: 15^{*}$ & Clear and colorless \\
\hline & 4 & $\mathrm{HNO}_{3}: \mathrm{HClO}_{4}$ & $4: 1$ & 270 & $2: 30$ & Clear and colorless \\
\hline & 5 & $\mathrm{HNO}_{3}: \mathrm{HClO}_{4}$ & $4: 1$ & 270 & $2: 45$ & Clear and colorless \\
\hline & 6 & $\mathrm{HNO}_{3}: \mathrm{HClO}_{4}$ & $4: 1$ & 270 & $3: 00$ & Clear and colorless \\
\hline \multicolumn{7}{|c|}{ L. vulgare } \\
\hline \multirow{2}{*}{ : } & 1 & $\mathrm{HNO}_{3}: \mathrm{HClO}_{4}$ & $3: 3$ & 300 & $3: 00$ & Deep yellow \\
\hline & 2 & $\mathrm{HNO}_{3}: \mathrm{HClO}_{4}$ & $4: 2$ & 300 & $3: 00$ & Deep yellow \\
\hline
\end{tabular}




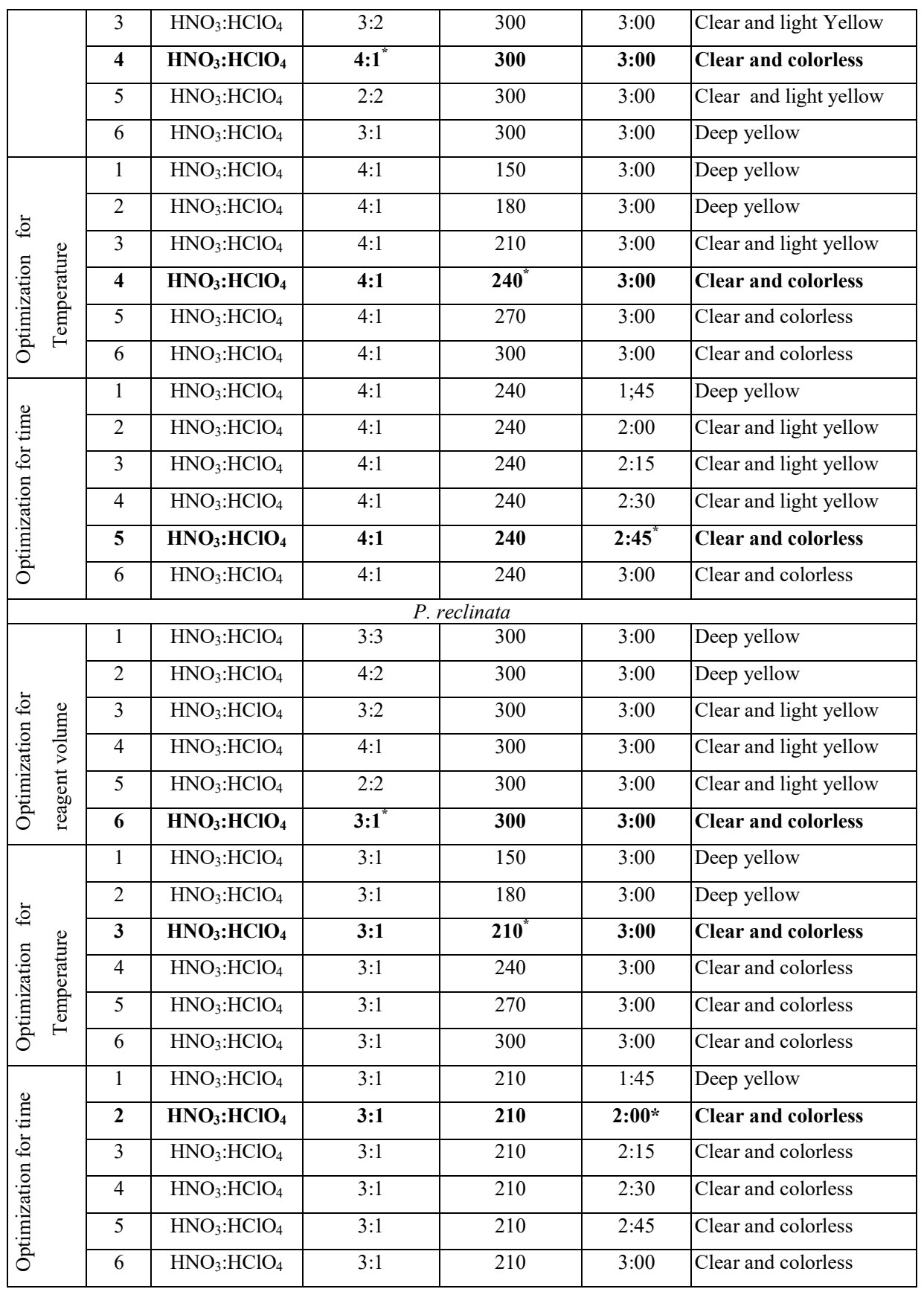

*The bold font indicates the optimum condition. 
Digestion of traditional toothbrushes samples

A $0.5 \mathrm{~g}$ of each dried and homogenized samples were transferred to individual $250 \mathrm{~mL}$ round bottom flask, and a total of $5 \mathrm{~mL}$ of the mixture of nitric acid $(69.5 \%)$ and perchloric acid $(70 \%)$ with a volume ratio of $4: 1(\mathrm{v} / \mathrm{v})$ for $O$. africana and $4: 1(\mathrm{v} / \mathrm{v})$ for $L$. vulgare and total $4 \mathrm{~mL}$ of the mixture of nitric acid (69.5\%) and perchloric acid (70\%) with a volume ratio of $3: 1(\mathrm{v} / \mathrm{v})$ for $P$. reclinata sample was added and the mixture was digested on a Kjeldahl digestion apparatus fitting the flask to a reflux condenser by setting the temperature at $270{ }^{\circ} \mathrm{C}, 240{ }^{\circ} \mathrm{C}$, and $210{ }^{\circ} \mathrm{C}$ for 2:15, 2:45, and 2:00 hours, respectively. The digest was allowed to cool to room temperature for $10 \mathrm{~min}$ without dismantling the condenser from the flask and a further $10 \mathrm{~min}$ after removing the condenser. To the cooled solution, $20 \mathrm{~mL}$ of deionized water was added to dissolve the precipitate formed on cooling and to minimize dissolution of filter paper by the digest residue while filtering with Whatman $(110 \mathrm{~mm}$ diameter) filter paper in to $50 \mathrm{~mL}$ volumetric flask. The round bottom flask was rinsed subsequently with $5 \mathrm{~mL}$ deionized water until the total volume was reached around $45 \mathrm{~mL}$ and finally the solution was diluted to $50 \mathrm{~mL}$.

\section{Calibration of MP-AES instrument}

Working standard solutions were prepared for each of the metals from an intermediate standard solution containing $10 \mathrm{mg} / \mathrm{L}$, which was prepared from the atomic absorption spectroscopy stock standard solutions that contained $1000 \mathrm{mg} / \mathrm{L}$. These standards were diluted with deionized water to obtain four working standards for each metal of interest. The selected metals (Al, Ca, $\mathrm{Mg}, \mathrm{Cu}, \mathrm{Zn}, \mathrm{Mn}, \mathrm{Ni}, \mathrm{Fe}, \mathrm{Cr}, \mathrm{Pb}$ and $\mathrm{Cd}$ ) in the digest from three different traditional toothbrush samples from three different areas were determined three times by MP-AES.

It should be noted that even though the MP-AES is multi-element technique, working standard solution of each metal individually is required for the construction of calibration curve of individual metal.

Table 2. The wavelength, method detection limit correlation coefficient and calibration curve equations.

\begin{tabular}{|c|c|c|c|c|l|}
\hline Metal & $\begin{array}{c}\text { Wavelength } \\
(\mathrm{nm})\end{array}$ & $\begin{array}{c}\mathrm{MDL} \\
(\mathrm{mg} / \mathrm{kg})\end{array}$ & $\begin{array}{c}\mathrm{MQL} \\
(\mathrm{mg} / \mathrm{kg})\end{array}$ & $\begin{array}{c}\text { Correlation } \\
\text { coefficient }\end{array}$ & $\begin{array}{l}\text { Calibration curve } \\
\text { Equation }\end{array}$ \\
\hline $\mathrm{Ca}$ & 422.673 & 0.285 & 0.95 & 0.998 & $\mathrm{y}=66713 \mathrm{c}+32373$ \\
\hline $\mathrm{Mg}$ & 279.553 & 0.364 & 1.21 & 0.999 & $\mathrm{y}=19334 \mathrm{c}+1884$ \\
\hline $\mathrm{Cu}$ & 327.395 & 0.21 & 0.699 & 0.999 & $\mathrm{y}=33562 \mathrm{c}+525.3$ \\
\hline $\mathrm{Zn}$ & 213.857 & 0.163 & 0.543 & 0.999 & $\mathrm{y}=4541 \mathrm{c}+301.9$ \\
\hline $\mathrm{Mn}$ & 259.372 & 0.188 & 0.626 & 0.999 & $\mathrm{y}=2977 \mathrm{c}+206.3$ \\
\hline $\mathrm{Ni}$ & 305.081 & 0.96 & 3.195 & 0.999 & $\mathrm{y}=4453 \mathrm{c}+270.2$ \\
\hline $\mathrm{Fe}$ & 371.993 & 0.39 & 1.298 & 0.999 & $\mathrm{y}=5024 \mathrm{c}+203.5$ \\
\hline $\mathrm{Cr}$ & 427.480 & 0.77 & 3.85 & 0.999 & $\mathrm{y}=21959 \mathrm{c}-180.5$ \\
\hline $\mathrm{Cd}$ & 226.502 & - & - & 0.998 & $\mathrm{y}=660.3 \mathrm{c}+118.9$ \\
\hline $\mathrm{Pb}$ & 368.346 & - & - & 0.999 & $\mathrm{y}=1722 \mathrm{c}+6.594$ \\
\hline $\mathrm{Al}$ & 396.152 & 0.31 & 1.03 & 0.999 & $\mathrm{y}=24298 \mathrm{c}+753.3$ \\
\hline
\end{tabular}

Method detection limit (MDL)

Limit of detection (LOD) is the smallest amount or concentration that can be detected by the analytical method with a given certainty. Limit of detection can be calculated by multiplying the standard deviation of the blank $\left(\mathrm{SD}_{\mathrm{b}}\right)$ by three $\left(\mathrm{LOD}=3 \mathrm{SD}_{\mathrm{b}}\right)$. The detection limit (with all steps of the analysis included) is called the MDL. The limit of quantification (LOQ) is the smallest quantity of analyte that can be measured with acceptable accuracy and precision and it is described as 10 times the standard deviation of the blank. The wavelength, method detection 
limit (MDL), method quantification limit (MQL), correlation coefficient and calibration curve equations are given in Table 2.

The wavelengths for the selected metals listed in Table 2 are apparently looks in contradiction to reported wavelengths. This is because MP-AES is an optical emission spectrometer. The wavelengths were selected according to the manual of the instrument provided by the manufacturer and the instrument was operated in emission mode.

\section{Validation of digestion procedure}

The validity of the digestion procedures was assured by spiking the samples with a standard solution of known concentration of target analaytes. For this purpose a stock standard solution of $1000 \mathrm{mg} / \mathrm{L}$ of each analayte was used. Thus, spiking was done for one of the three samples that is $O$. africana branch sample in triplicates. From the stock solution of $1000 \mathrm{mg} / \mathrm{L}, 4.5 \mu \mathrm{L}$ of $\mathrm{Zn}, 1.5 \mu \mathrm{L}$ of $\mathrm{Cr}, 3.6 \mu \mathrm{L}$ of $\mathrm{Cu}, 1 \mu \mathrm{L}$ of $\mathrm{Ni}, 4.4 \mu \mathrm{L}$ of $\mathrm{Mn}$, and $27.7 \mu \mathrm{L}$ of Fe were added to 0.5 $\mathrm{g}$ of $O$. africana sample. These small volumes of solutions were measured using a micropipette of the volume range 1-20 $\mu \mathrm{L}$. The spiked and unspiked samples were digested and analyzed in a similar manner. As shown in Table 3, selected metals were analyzed in triplicate to evaluate the efficiency of the procedure and the percentage recoveries lies within the range from 91 to $107 \%$.

The spiking experiment was performed only for $O$. africana. This is because the digestion procedures for the three plants are not much different and the analysis procedure is the same for all the three plants.

Table 3. Analytical results for recovery test of $O$. africana sample.

\begin{tabular}{|c|c|c|c|c|c|}
\hline Metals & $\begin{array}{c}\text { Concentration of unspike } \\
\text { sample (mg/kg) }\end{array}$ & $\begin{array}{c}\% \\
\text { spiking }\end{array}$ & $\begin{array}{c}\text { Amount } \\
\text { added }(\mathrm{mg} / \mathrm{kg})\end{array}$ & $\begin{array}{c}\text { Spiked sample } \\
(\mathrm{mg} / \mathrm{kg})\end{array}$ & $\begin{array}{c}\% \\
\text { Recovery }\end{array}$ \\
\hline $\mathrm{Zn}$ & $35.1 \pm 0.1$ & 25 & 8.78 & $43.1 \pm 3.0$ & 91.0 \\
\hline $\mathrm{Cr}$ & $6.68 \pm 0.1$ & 45 & 3.0 & $9.49 \pm 0.74$ & 93.7 \\
\hline $\mathrm{Cu}$ & $17.9 \pm 1.7$ & 40 & 7.16 & $24.9 \pm 0.72$ & 97.8 \\
\hline $\mathrm{Ni}$ & $3.6 \pm 0.2$ & 50 & 1.8 & $5.43 \pm 0.36$ & 102 \\
\hline $\mathrm{Mn}$ & $29.0 \pm 1.1$ & 30 & 8.7 & $37.1 \pm 4.9$ & 93.0 \\
\hline $\mathrm{Fe}$ & $221 \pm 19.9$ & 25 & 55.3 & $280.3 \pm 1.2$ & 107 \\
\hline
\end{tabular}

\section{Statistical analysis}

The analysis of variances (ANOVA) and the correlation among metals were assessed by Pearson correlation methods and the graphical expression was done using Microsoft excel 7.

\section{RESULTS AND DISCUSSION}

The concentrations of metals shown in Table 4 were determined by using MP-AES and precision of the results were assessed as relative standard deviation. The relative standard deviation of the results with a few exception were less than or equal to $10 \%$ which is within the recommended range. Mean values were determined from triplicate analysis of each sample and triplicate samples were used for each sample site.

\section{Concentration of metals in L. vulgare samples}

As shown in Table 4, the maximum concentration of elements $\mathrm{Ca}, \mathrm{Fe}, \mathrm{Zn}, \mathrm{Al}, \mathrm{Mg}, \mathrm{Mn}, \mathrm{Cu}, \mathrm{Cr}$, and $\mathrm{Ni}$ are 6143, 318, 175, 143, $102,26.7,12.6,8.9$ and $4.8 \mathrm{mg} / \mathrm{kg}$, respectively, in the $L$. vulgare samples. Similarly, the minimum concentration of elements $\mathrm{Ca}, \mathrm{Fe}, \mathrm{Zn}, \mathrm{Al}, \mathrm{Mg}, \mathrm{Mn}$, 
$\mathrm{Cu}, \mathrm{Cr}$ and $\mathrm{Ni}$ are 5619, 216, 134, 126, 89, 22.6, 10.2, 6.3 and $3.9 \mathrm{mg} / \mathrm{kg}$, respectively, in $L$. vulgare samples. The results showed that the $L$. vulgare samples collected from Kotebe site have higher amounts of $\mathrm{Zn}, \mathrm{Cr}, \mathrm{Cu}, \mathrm{Ni}, \mathrm{Mg}, \mathrm{Al}, \mathrm{Ca}$, and $\mathrm{Fe}$ compared to the concentrations of those metals in L. vulgare samples from other sample sites. But the concentrations of $\mathrm{Mn}$ in samples collected from Arat Kilo sample site was higher than samples collected at Kotebe and Ferensay sample sites. The concentrations of $\mathrm{Cd}$ and $\mathrm{Pb}$ in the L. vulgare samples collected from the three different sample sites were below detection limit. The concentrations of $\mathrm{Ca}$ are higher than other metals and the concentrations of Ni are lower as compared to other metals in L. vulgare samples collected from the sites.

Table 4. Concentration of metals $(\mathrm{mg} / \mathrm{kg}$, mean $\pm \mathrm{SD}, \mathrm{n}=3)$ in traditional toothbrushes obtained from $L$. vulgare, P. reclinata and $O$. afiricana

\begin{tabular}{|c|c|c|c|c|c|c|c|c|c|}
\hline \multirow{3}{*}{ Metals } & \multicolumn{9}{|c|}{ Concentration of metals (mg/kg, mean \pm SD, $\mathrm{n}=3$ ) } \\
\cline { 2 - 11 } & \multicolumn{3}{|c|}{ L. vulgare } & \multicolumn{3}{c|}{ P. reclinata } & \multicolumn{3}{c|}{ O. afiricana } \\
\cline { 2 - 11 } & Kotebe & Arat Kilo & Ferensay & Kotebe & Arat Kilo & Ferensay & Kotebe & Arat Kilo & Ferensay \\
\hline $\mathrm{Zn}$ & $175 \pm 11.9$ & $134 \pm 1.2$ & $145 \pm 2.4$ & $29.5 \pm 0.6$ & $47.8 \pm 2.4$ & $27.2 \pm 1.3$ & $36.8 \pm 1.2$ & $45.7 \pm 4.1$ & $35.1 \pm 0.1$ \\
\hline $\mathrm{Cr}$ & $8.9 \pm 0.8$ & $8.8 \pm 0.1$ & $6.3 \pm 0.7$ & $8.6 \pm 0.1$ & $8.3 \pm 0.3$ & $8.2 \pm 0.7$ & $7.66 \pm 0.5$ & $7.0 \pm 0.5$ & $6.7 \pm 0.1$ \\
\hline $\mathrm{Cu}$ & $12.6 \pm 0.4$ & $10.4 \pm 0.7$ & $10.2 \pm 0.8$ & $6.6 \pm 0.4$ & $12.5 \pm 0.5$ & $10.3 \pm 1.0$ & $10.1 \pm 0.9$ & $20.3 \pm 0.6$ & $17.9 \pm 1.7$ \\
\hline $\mathrm{Ni}$ & $4.8 \pm 0.4$ & $4.7 \pm 0.5$ & $3.9 \pm 0.2$ & $7.9 \pm 1.1$ & $4.4 \pm 0.3$ & $2.6 \pm 0.2$ & $4.9 \pm 1.1$ & $3.5 \pm 0.2$ & $3.6 \pm 0.2$ \\
\hline $\mathrm{Mn}$ & $24.9 \pm 1.2$ & $26.7 \pm 2.6$ & $22.6 \pm 0.6$ & $15.1 \pm 0.9$ & $20.1 \pm 1.1$ & $16.6 \pm 0.5$ & $23.7 \pm 1$ & $20.7 \pm 0.5$ & $29.0 \pm 1.1$ \\
\hline $\mathrm{Mg}$ & $102 \pm 8$ & $94 \pm 2$ & $89 \pm 5$ & $75 \pm 1$ & $55 \pm 5$ & $46 \pm 4$ & $122 \pm 4$ & $117 \pm 4$ & $108 \pm 8$ \\
\hline $\mathrm{Al}$ & $143 \pm 13.1$ & $136 \pm 12.0$ & $126 \pm 5.2$ & $121 \pm 3.1$ & $115 \pm 9.4$ & $81.6 \pm 0.7$ & $224 \pm 12.1$ & $200 \pm 6.1$ & $224 \pm 5.2$ \\
\hline $\mathrm{Ca}$ & $6143 \pm 535$ & $5619 \pm 554$ & $6061 \pm 293$ & $7397 \pm 593$ & $36514 \pm 2991$ & $27676 \pm 2800$ & $4267 \pm 368$ & $23414 \pm 699$ & $28178 \pm 2142$ \\
\hline $\mathrm{Fe}$ & $318 \pm 34.4$ & $235 \pm 14.1$ & $216 \pm 8.2$ & $168 \pm 12$ & $200 \pm 6.9$ & $131 \pm 4.5$ & $194 \pm 14$ & $275 \pm 9.9$ & $221 \pm 19.9$ \\
\hline $\mathrm{Pb}$ & BDL & BDL & BDL & BDL & BDL & BDL & BDL & BDL & BDL \\
\hline $\mathrm{Cd}$ & BDL & BDL & BDL & BDL & BDL & BDL & BDL & BDL & BDL \\
\hline $\mathrm{BDL}$ & & & & & & & &
\end{tabular}

$\mathrm{BDL}=$ below detection limit.

\section{Concentration of metals in P. reclinata samples}

As shown in Table 4, the maximum concentration of metals $\mathrm{Ca}, \mathrm{Fe}, \mathrm{Al}, \mathrm{Mg}, \mathrm{Zn}, \mathrm{Mn}, \mathrm{Cu}, \mathrm{Cr}$, and $\mathrm{Ni}$ are $36514,200,121,75,47.8,20.1,12.5,8.6$, and $7.9 \mathrm{mg} / \mathrm{kg}$, respectively, in the $P$. reclinata samples. Similarly, the minimum concentration for elements $\mathrm{Ca}, \mathrm{Fe}, \mathrm{Al}, \mathrm{Zn}, \mathrm{Mg}, \mathrm{Mn}$, $\mathrm{Cu}, \mathrm{Cr}$, and $\mathrm{Ni}$ are $7397,131,81.6,46,27.2,15.1,6.6,8.2$, and $2.6 \mathrm{mg} / \mathrm{kg}$, respectively, in $P$. reclinata samples. The results showed that the $P$. reclinata samples collected from Arat Kilo site have higher amounts of $\mathrm{Zn}, \mathrm{Cu}, \mathrm{Mn}, \mathrm{Ca}$, and $\mathrm{Fe}$ compared to the concentration of the metals in $P$. reclinata samples from other sample sites. But the concentrations of $\mathrm{Cr}, \mathrm{Ni}, \mathrm{Mg}$, and $\mathrm{Al}$ in $P$. reclinata samples collected from Kotebe sample site are higher than samples collected Arat Kilo and Ferensay sample sites. The concentrations of $\mathrm{Cd}$ and $\mathrm{Pb}$ in $P$. reclinata samples collected from three different sample sites are below detection limit. The concentration of $\mathrm{Ca}$ was higher than other metals and the concentration of $\mathrm{Ni}$ was lower than other metals in $P$. reclinata samples collected from three different sample sites.

\section{Concentration of metals in O. africana samples}

As shown in Table 4, the maximum concentration of metals $\mathrm{Ca}, \mathrm{Fe}, \mathrm{Al}, \mathrm{Mg}, \mathrm{Zn}, \mathrm{Mn}, \mathrm{Cu}, \mathrm{Cr}$, and $\mathrm{Ni}$ are 28178, 275, 224, 122, 45.7, 29.0, 20.3, 7.66, and $4.9 \mathrm{mg} / \mathrm{kg}$, respectively, in the $O$. africana samples. Similarly, the minimum concentration levels for elements $\mathrm{Ca}, \mathrm{Fe}, \mathrm{Al}, \mathrm{Mg}, \mathrm{Zn}$, $\mathrm{Mn}, \mathrm{Cu}, \mathrm{Cr}$, and $\mathrm{Ni}$ are 4267, 194, 200, 108, 35.1, 20.7, 10.1, 6.7 and $3.5 \mathrm{mg} / \mathrm{kg}$, respectively, in $O$. africana samples. The results of concentrations of metals showed that the $O$. africana samples collected from Ferensay site have higher amounts of $\mathrm{Mn}, \mathrm{Al}$, and $\mathrm{Ca}$, and $O$. africana 
samples collected from Arat kilo site have higher amounts of $\mathrm{Fe}, \mathrm{Zn}$, and $\mathrm{Cu}$, and $O$. africana samples collected from Kotebe site have higher amounts of $\mathrm{Cr}, \mathrm{Ni}$, and $\mathrm{Mg}$ as compared to the concentration of metals in $O$. africana samples from other sample sites. The concentrations of $\mathrm{Cd}$ and $\mathrm{Pb}$ in $\mathrm{O}$. africana samples collected from three different sample sites were below detection limit. The concentration of $\mathrm{Ca}$ was the highest compared to other metals and the concentration of $\mathrm{Ni}$ was the lowest compared to other metals in in O. africana samples collected from the three different sample sites.

Comparison of metal concentrations $(\mathrm{mg} / \mathrm{kg})$ in L. vulgare, P. reclinata, and $O$. africana samples

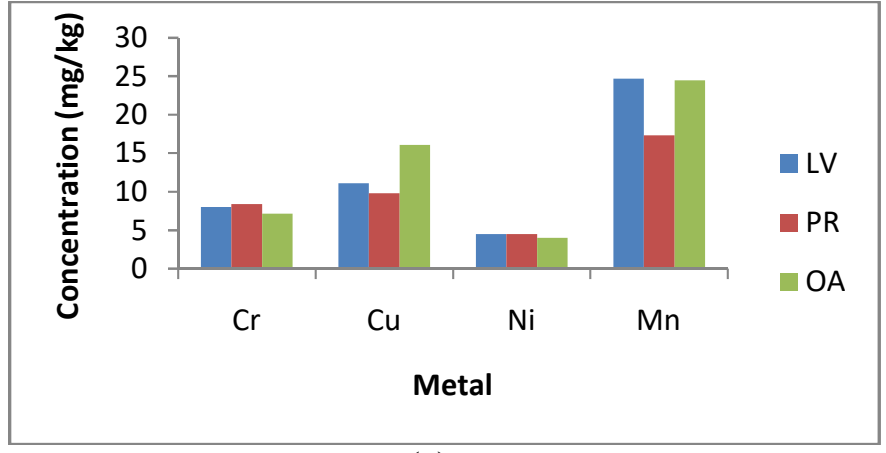

(a)
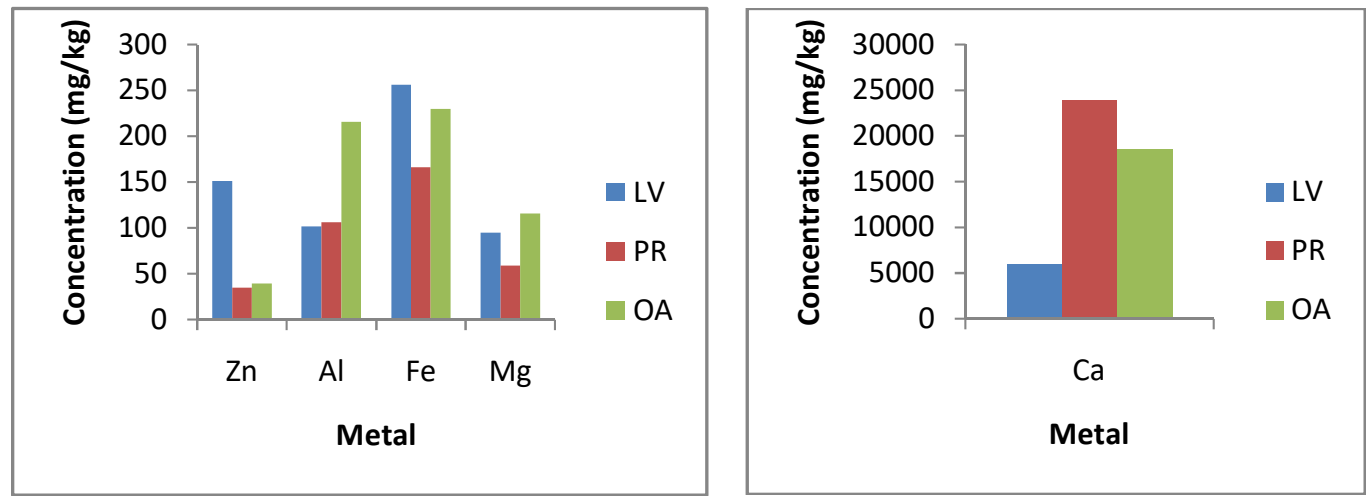

(b)

Figure 2. Comparison of metals concentration (A) $\mathrm{Cr}, \mathrm{Cu}, \mathrm{Ni}$, and $\mathrm{Mn}$ and (B) $\mathrm{Zn}, \mathrm{Mg}, \mathrm{Al}$, and Fe and (C) $\mathrm{Ca}$ in L. vulgare (LV), P. reclinata $(\mathrm{PR})$, and $O$. africana $(\mathrm{OA})$ samples.

Comparison of metal concentrations $(\mathrm{mg} / \mathrm{kg})$ in the traditional toothbrushes from $L$. vulgare, $P$. reclinata, and $O$. africana are shown in Figure 2. The metals are grouped according to their concentrations and not according to their classification as essential, trace or toxic metals. The results of this study showed that there is a variation in the metal contents of the three traditional toothbrushes. This variation may be due to genetic factors and can also be due to environmental factors as well. The highest concentration of $\mathrm{Ca}(23862 \mathrm{mg} / \mathrm{kg})$ was observed in P. reclinata 
samples as compared to concentration of Ca in L. vulgare $(5941 \mathrm{mg} / \mathrm{kg})$ and $O$. africana $(18620$ $\mathrm{mg} / \mathrm{kg}$ ) samples, respectively. The concentration of $\mathrm{Ni}$ was the lowest in the three traditional toothbrushes as compared to the concentrations of other selected metals. The highest concentration of $\mathrm{Ca}, \mathrm{Fe}, \mathrm{Al}, \mathrm{Mg}$ and $\mathrm{Zn}$ were observed in the three traditional toothbrush samples and relatively lower amounts of $\mathrm{Cr}, \mathrm{Cu}, \mathrm{Ni}$ and $\mathrm{Mn}$ were observed compared to concentration of $\mathrm{Ca}, \mathrm{Fe}, \mathrm{Al}, \mathrm{Mg}$ and $\mathrm{Zn}$.

Comparison of metals concentration ( $\mathrm{mg} / \mathrm{kg}$, dry mass) of the three traditional toothbrushes with other medicinal plants reported in literature

The metal concentrations $(\mathrm{mg} / \mathrm{kg}$, dry mass) in the three Ethiopian traditional toothbrushes are compared with other medicinal plants reported in literature. The results are summarized in Table 5. The $\mathrm{Ca}$ contents determined in the three traditional toothbrushes are higher than $\mathrm{Ca}$ contents in other medicinal plants: Rhamnus prinoides [27] and Zingiber officinal [28]. The Mg contents determined in this study are lower compared with Mg contents determined from other medicinal plants like Rhamnus prinoides and Zingiber officinal reported by Gebre and Chandravanshi [27] and Wagesho and Chandravanshi [28]. The concentrations of Fe and $\mathrm{Al}$ in this study are higher than concentrations of $\mathrm{Fe}$ and $\mathrm{Al}$ from other medicinal plants reported. The concentrations of other metals such as $\mathrm{Ni}, \mathrm{Cr}, \mathrm{Zn}$ and $\mathrm{Cu}$ in this study and the reported values from the medicinal plants are comparable. The concentrations of $\mathrm{Pb}$ and $\mathrm{Cd}$ in this study were below detection limit.

Table 5. Comparison of metals concentration ( $\mathrm{mg} / \mathrm{kg}$, dry mass) of the three traditional toothbrushes with other medicinal plants reported in the literature.

\begin{tabular}{|c|c|c|c|c|c|c|c|c|c|}
\hline \multirow[t]{2}{*}{ Plant types } & \multirow{2}{*}{$\begin{array}{l}\text { Plant } \\
\text { parts }\end{array}$} & \multirow[t]{2}{*}{ Country } & \multirow[t]{2}{*}{ Method } & \multicolumn{5}{|c|}{ Metal concentration $(\mathrm{mg} / \mathrm{kg})$} & \multirow[t]{2}{*}{ Reference } \\
\hline & & & & $\mathrm{Pb}$ & $\mathrm{Cd}$ & $\mathrm{Cu}$ & $\mathrm{Zn}$ & $\mathrm{Fe}$ & \\
\hline $\begin{array}{l}\text { Rhamnus } \\
\text { prinoides }\end{array}$ & Branch & Ethiopia & FAAS & ND & $1.0-1.26$ & $16.8-233$ & $17.4-28.2$ & $22-124$ & [27] \\
\hline $\begin{array}{l}\text { Zingiber } \\
\text { officinale }\end{array}$ & Root & Ethiopia & FAAS & BDL & $0.38-0.97$ & $1.1-4.78$ & $38.5-55.2$ & $41.8-89$ & [28] \\
\hline $\begin{array}{l}\text { Phoenix } \\
\text { dactylifera }\end{array}$ & Fruit & & ICP-AES & $0.78-5.83$ & $0.04-0.18$ & $0.92-1.53$ & $0.23-0.95$ & $120-315$ & [29] \\
\hline $\begin{array}{l}\text { Phoenix } \\
\text { reclinata }\end{array}$ & Branch & Ethiopia & MP-AES & BDL & BDL & $6.6-12.5$ & $27.2-47.8$ & $131-200$ & This study \\
\hline $\begin{array}{l}\text { Ligustrum } \\
\text { valgare }\end{array}$ & Branch & Ethiopia & MP-AES & BDL & BDL & $10.2-12.6$ & $134-175$ & $216-318$ & This study \\
\hline \begin{tabular}{|l} 
Olea \\
africana
\end{tabular} & Branch & Ethiopia & MP-AES & BDL & BDL & 10.1-20.3 & $31.5-45.7$ & $194-275$ & This study \\
\hline
\end{tabular}

\begin{tabular}{|c|c|c|c|c|c|c|c|c|c|c|}
\hline \multirow[t]{2}{*}{ Plant types } & \multirow[t]{2}{*}{ Parts } & \multirow[t]{2}{*}{ Country } & \multirow[t]{2}{*}{ Method } & \multicolumn{6}{|c|}{ Metal concentration $(\mathrm{mg} / \mathrm{kg})$} & \multirow[t]{2}{*}{ References } \\
\hline & & & & $\mathrm{Cr}$ & $\mathrm{Ca}$ & $\mathrm{Mg}$ & $\mathrm{Mn}$ & $\mathrm{Ni}$ & $\mathrm{Al}$ & \\
\hline $\begin{array}{l}\text { Rhamnus } \\
\text { prinoides }\end{array}$ & Branch & Ethiopia & FAAS & $5.42-17.4$ & $360-5750$ & $\begin{array}{c}2635- \\
5528\end{array}$ & $2.16-3.98$ & 9.68 & ND & {$[27]$} \\
\hline $\begin{array}{l}\text { Zingiber } \\
\text { officinal }\end{array}$ & Stem & Ethiopia & FAAS & $6.02-10.8$ & $200-2543$ & $\begin{array}{c}2700- \\
4094 \\
\end{array}$ & $184-401$ & $5.46-8.4$ & ND & [28] \\
\hline \begin{tabular}{|l|} 
Phoenix \\
dactylifera
\end{tabular} & Fruit & Saudi & ICP-AES & ND & $110-200$ & ND & $31.8-89.3$ & $8-11.75$ & $13.6-74.9$ & [29] \\
\hline $\begin{array}{l}\text { Phoenix } \\
\text { reclinata }\end{array}$ & Branch & Ethiopia & MP-AES & $8.2-8.6$ & $\begin{array}{l}7397- \\
36514 \\
\end{array}$ & $89-102$ & $15-20.1$ & $2.6-7.9$ & $81.6-121$ & This study \\
\hline \begin{tabular}{|l} 
Ligustrum \\
valgare
\end{tabular} & Branch & Ethiopia & MP-AES & $6.3-8.9$ & $5619-6143$ & $46-75$ & $22.6-26.7$ & $3.9-4.8$ & $126-143$ & This study \\
\hline $\begin{array}{l}\text { Olea } \\
\text { africana }\end{array}$ & Branch & Ethiopia & MP-AES & $6.7-7.66$ & $\begin{array}{l}4267- \\
28178\end{array}$ & $108-122$ & $20.7-29$ & $3.5-4.9$ & $200-224$ & This study \\
\hline
\end{tabular}

$\mathrm{ND}=$ not detected, $\mathrm{BDL}=$ below detection limit. 
Comparison of metals concentration $(\mathrm{mg} / \mathrm{kg})$ of the three traditional toothbrushes with toothpastes metals concentrations reported in the literature

The metal concentrations $(\mathrm{mg} / \mathrm{kg})$ in the three traditional toothbrushes are compared with the metals concentrations in commercial toothpastes reported in the literature. The results are summarized in Table 6. The concentrations of Ni are higher in local toothpastes used in Nigeria and toothpastes imported to Nigeria as compared to this study, but the concentration of $\mathrm{Ni}$ in other commercial toothpastes is comparable to this study. The concentrations of $\mathrm{Fe}, \mathrm{Cu}$ and $\mathrm{Mn}$ in this study are higher as compared to concentrations in commercial toothpastes. The concentrations of $\mathrm{Cr}$ in the local toothpastes used in Nigeria and toothpastes imported to Nigeria are comparable to the values of this study. The concentration of $\mathrm{Zn}$ in commercial toothpastes is higher than in present study. The toxic metals $\mathrm{Pb}$ and $\mathrm{Cd}$ concentrations in commercial toothpastes in Malta, local toothpastes in Nigeria, toothpastes imported to Nigeria are present in appreciable amount, but were below detection limit in the three Ethiopian traditional toothbrushes, which is preferable.

Table 6. Comparison of metals concentration $(\mathrm{mg} / \mathrm{kg})$ of the three traditional toothbrushes with other toothpastes metals concentrations reported in the literature.

\begin{tabular}{|c|c|c|c|c|c|c|c|c|}
\hline \multirow{2}{*}{$\begin{array}{l}\text { Type of } \\
\text { toothpaste }\end{array}$} & \multirow[t]{2}{*}{ Country } & \multirow[t]{2}{*}{ Method } & \multicolumn{5}{|c|}{ Metal concentration $(\mathrm{mg} / \mathrm{kg})$} & \multirow[t]{2}{*}{ Reference } \\
\hline & & & $\mathrm{Cd}$ & $\mathrm{Cr}$ & $\mathrm{Cu}$ & $\mathrm{Ni}$ & $\mathrm{Pb}$ & \\
\hline $\begin{array}{l}\text { Commercial } \\
\text { toothpastes }\end{array}$ & Malta & MP-AES & - & $0.28-7.35$ & $0.73-3.68$ & $0.43-2.54$ & $2.23-12.04$ & [30] \\
\hline $\begin{array}{l}\text { Local } \\
\text { toothpastes }\end{array}$ & Nigeria & FAAS & $0.001-1.284$ & $0.001-5.97$ & ND & $5.472-18.63$ & $\begin{array}{l}4.514- \\
23.575\end{array}$ & [31] \\
\hline $\begin{array}{l}\text { Commercial } \\
\text { toothpastes }\end{array}$ & Nigeria & FAAS & $0.001-2.49$ & $\begin{array}{l}0.001- \\
10.85\end{array}$ & ND & $\begin{array}{l}8.975- \\
18.535 \\
\end{array}$ & $\begin{array}{l}6.329- \\
18.092 \\
\end{array}$ & [31] \\
\hline $\begin{array}{l}\text { Commercial } \\
\text { toothpastes }\end{array}$ & India & AAS & $<0.031$ & - & - & - & $0.84-1.58$ & [32] \\
\hline $\begin{array}{l}\text { Ligustrum } \\
\text { vulgare }\end{array}$ & Ethiopia & MP-AES & BDL & $6.3-8.9$ & $10.2-12.6$ & $3.9-4.8$ & BDL & This study \\
\hline \begin{tabular}{|l|} 
Olea \\
africana
\end{tabular} & Ethiopia & MP-AES & BDL & $6.7-7.66$ & $10.1-20.3$ & $3.5-4.9$ & $\mathrm{BDL}$ & This study \\
\hline $\begin{array}{l}\text { Phoenix } \\
\text { reclinata }\end{array}$ & Ethiopia & MP-AES & BDL & $8.2-8.6$ & $6.6-12.5$ & $2.6-7.9$ & BDL & This study \\
\hline
\end{tabular}

\begin{tabular}{|l|c|c|c|c|c|c|}
\hline \multirow{2}{*}{$\begin{array}{l}\text { Type of } \\
\text { toothpaste }\end{array}$} & Country & Method & \multicolumn{3}{|c|}{ Metal concentration (mg/kg) } & Reference \\
\cline { 4 - 7 } & & & $\mathrm{Fe}$ & $\mathrm{Mn}$ & $\mathrm{Zn}$ & \\
\hline $\begin{array}{l}\text { Commercial } \\
\text { toothpastes }\end{array}$ & Malta & MP-AES & $1.76-17.7$ & $0.2-2.02$ & $0.00-2417$ & {$[30]$} \\
\hline $\begin{array}{l}\text { Ligustrum } \\
\text { vulgare }\end{array}$ & Ethiopia & MP-AES & $216-318$ & $22.6-26.7$ & $134-175$ & This study \\
\hline $\begin{array}{l}\text { Olea africana } \\
\text { Phoenix } \\
\text { reclinata }\end{array}$ & Ethiopia & MP-AES & $194-275$ & $20.7-29$ & $31.5-45.7$ & This study \\
\hline
\end{tabular}

Comparison of maximum heavy metal contents in the traditional toothbrush samples with the international standards in cosmetics and toothpastes

The maximum heavy metal contents in Ethiopian traditional toothbrush samples are compared with available international standards in toothpastes (Table 7). The toxic heavy metals $\mathrm{Pb}$ and $\mathrm{Cd}$ were not detected in Ethiopian traditional toothbrush samples while $\mathrm{Ni}$ and $\mathrm{Cr}$ are within the range of international standards for toothpastes. Therefore, the Ethiopian traditional toothbrushes are found to be safe for human use. 
Table 7. Comparison of heavy metal contents $(\mathrm{mg} / \mathrm{kg})$ in the traditional toothbrush samples with available international standards in cosmetics and toothpastes.

\begin{tabular}{|l|c|c|c|c|c|}
\hline International standards & $\mathrm{Pb}$ & $\mathrm{Cd}$ & $\mathrm{Ni}$ & $\mathrm{Cr}$ & Reference \\
\hline European Union & 0.1 & 0.05 & - & - & {$[33]$} \\
\hline World Health Organization & 2 & 2 & - & - & {$[34]$} \\
\hline Canada & 10 & 3 & - & - & {$[35]$} \\
\hline Germany & 0.5 & 0.1 & - & - & This study \\
\hline $\begin{array}{l}\text { Ethiopian traditional } \\
\text { toothbrushes }\end{array}$ & $\mathrm{BDL}$ & $\mathrm{BDL}$ & $2.6-7.9$ & $6.3-8.6$ & {$[33]$} \\
\hline
\end{tabular}

$\mathrm{BDL}=$ below detection limit.

Analysis of variance (ANOVA)

Analysis of variance (ANOVA) is a statistical method used to test differences between two or more means. ANOVA use the F statistic to compare whether the difference between sample means is significant or not [36]. In this study, traditional toothbrush samples were collected from three different areas and the metal levels of each sample were analysed by MP-AES. During the processes of sample preparation and analysis a number of random errors may be introduced in each aliquot and in each replicate measurement. The variation in sample mean of the analyte was tested by using ANOVA, whether the source for variation was from experimental procedure or heterogeneity among the samples (i.e., difference in mineral contents of soil, water, atmosphere; variation in application of agrochemicals like fertilizers, pesticides, herbicides etc or other variations in cultivation procedures). The results are summarized in Table 8.

Table 8. Analysis of variance (ANOVA) between Ligustrum vulgare, Phoenix reclinata and Olea africana samples at $95 \%$ confidence level.

\begin{tabular}{|c|c|c|c|c|c|c|c|c|c|}
\hline \multirow{2}{*}{ Metal } & \multicolumn{3}{|c|}{ Ligustrum vulgare } & \multicolumn{3}{c|}{ Phoenix reclinata } & \multicolumn{3}{c|}{ Olea africana } \\
\cline { 2 - 11 } & $\mathrm{F}_{\text {Calculated }}$ & $\mathrm{F}_{\text {Critical }}$ & $\mathrm{p}$-value & $\mathrm{F}_{\text {Calculated }}$ & $\mathrm{F}_{\text {Critical }}$ & $\mathrm{p}$-value & $\mathrm{F}_{\text {Calculated }}$ & $\mathrm{F}_{\text {Critical }}$ & $\mathrm{p}$-value \\
\hline $\mathrm{Zn}$ & 270 & 5.14 & $1.33 \times 10^{-6}$ & 114 & 5.14 & $1.7 \times 10^{-5}$ & 23.4 & 5.14 & 0.0015 \\
\hline $\mathrm{Cr}$ & 13.8 & 5.14 & 0.0057 & 0.15 & 5.14 & 0.86 & 61 & 5.14 & $9.99 \times 10^{-5}$ \\
\hline $\mathrm{Cu}$ & 181 & 5.14 & $4.36 \times 10^{-6}$ & 103 & 5.14 & $2.24 \times 10^{-5}$ & 81 & 5.14 & $4.45 \times 10^{-5}$ \\
\hline $\mathrm{Ni}$ & 61.3 & 5.14 & 0.000102 & 41.5 & 5.14 & 0.000307 & 4.12 & 5.14 & 0.075 \\
\hline $\mathrm{Mn}$ & 4.2 & 5.14 & 0.07 & 121 & 5.14 & $1.4 \times 10^{-5}$ & 222 & 5.14 & $2.36 \times 10^{-6}$ \\
\hline $\mathrm{Mg}$ & 13.0 & 5.14 & 0.0063 & 51.5 & 5.14 & 0.000167 & 4.86 & 5.14 & 0.0555 \\
\hline $\mathrm{Al}$ & 2.06 & 5.14 & 0.208 & 541 & 5.14 & $1.689 \times 10^{-7}$ & 144 & 5.14 & $8.59 \times 10^{-6}$ \\
\hline $\mathrm{Ca}$ & 1.06 & 5.14 & 0.405 & 117 & 5.14 & $1.56 \times 10^{-5}$ & 439 & 5.14 & $3.11 \times 10^{-7}$ \\
\hline $\mathrm{Fe}$ & 70 & 5.14 & $6.67 \times 10^{-5}$ & 250 & 5.14 & $1.67 \times 10^{-6}$ & 74.3 & 5.14 & $5.84 \times 10^{-5}$ \\
\hline
\end{tabular}

Results of ANOVA showed that there were significant differences $(p<0.05)$ in the mean values of $\mathrm{Cu}, \mathrm{Zn}, \mathrm{Ni}, \mathrm{Mg}, \mathrm{Cr}$, and $\mathrm{Fe}$ between $L$. vulgare samples while there was no significant difference $(\mathrm{p}>0.05)$ in the mean values of $\mathrm{Ca}, \mathrm{Mn}$, and $\mathrm{Al}$ between the samples.

Results of ANOVA showed that there were significant differences $(\mathrm{p}<0.05)$ for $\mathrm{Cu}, \mathrm{Zn}$, $\mathrm{Mn}, \mathrm{Ni}, \mathrm{Mg}, \mathrm{Al}, \mathrm{Ca}$, and $\mathrm{Fe}$ between $P$. reclinata samples while there was no significant difference $(\mathrm{p}>0.05)$ for $\mathrm{Cr}$ between these parameters.

Results of ANOVA showed that there were significant differences $(p<0.05)$ in the mean values of for $\mathrm{Cu}, \mathrm{Zn}, \mathrm{Mn}, \mathrm{Cr}, \mathrm{Al}, \mathrm{Ca}$, and $\mathrm{Fe}$ between $O$. africana samples while there was no significant difference $(\mathrm{p}>0.05)$ in the mean values of $\mathrm{Mg}$ and $\mathrm{Ni}$ between the three samples

Results of ANOVA showed that there were significant differences $(\mathrm{p}<0.05)$ in the mean values of for $\mathrm{Zn}, \mathrm{Mg}, \mathrm{Al}$ and $\mathrm{Mn}$ between $L$. vulgare, $P$. reclinata and $O$. africana samples while there was no significant difference $(\mathrm{p}>0.05)$ in the mean values of $\mathrm{Ca}, \mathrm{Cr}, \mathrm{Cu}, \mathrm{Fe}$ and $\mathrm{Ni}$ between the three samples. 
Pearson correlation of metals

The Pearson correlation coefficient ( $r$ ) is used to measure the strength of linear association between two variables [37]. In this study, to correlate the effect of one metal on the other metal, the Pearson correlation matrices using correlation coefficient $(r)$ for the samples were used. The correlation values are categorized as no correlation $(\mathrm{r}=0.00-0.19)$, weak correlation $(\mathrm{r}=0.20$ $0.5)$, medium correlation $(\mathrm{r}=0.50-0.75)$ and strong correlation $(\mathrm{r}=0.76-0.99)$. Linear regression correlations tests were performed to investigate the correlations between metal concentrations in the $L$. vulgare, $P$. reclinata and $O$. africana samples.

The correlation coefficients between metals in $L$. vulgare reflected strongly positive correlation between $\mathrm{Zn} / \mathrm{Cu}, \mathrm{Zn} / \mathrm{Mg} \mathrm{Cr} / \mathrm{Ni}, \mathrm{Cr} / \mathrm{Mg}$, Cu/Al, $\mathrm{Cu} / \mathrm{Mg}, \mathrm{Ni} / \mathrm{Mg}, \mathrm{Zn} / \mathrm{Ca}, \mathrm{Zn} / \mathrm{Fe}, \mathrm{Cr} / \mathrm{Mn}$, $\mathrm{Ni} / \mathrm{Mn}, \mathrm{Ni} / \mathrm{Al}, \mathrm{Cr} / \mathrm{Al}, \mathrm{Mg} / \mathrm{Al}, \mathrm{Al} / \mathrm{Fe}, \mathrm{Cu} / \mathrm{Fe}, \mathrm{Mg} / \mathrm{Fe}$, moderately positive correlation between $\mathrm{Zn} / \mathrm{Al}, \mathrm{Cu} / \mathrm{Ni}, \mathrm{Ni} / \mathrm{Fe}, \mathrm{Mn} / \mathrm{Al}, \mathrm{Cr} / \mathrm{Fe}, \mathrm{Cr} / \mathrm{Ca}, \mathrm{Cu} / \mathrm{Ca}$, moderately negative correlation between $\mathrm{Mn} / \mathrm{Ca}$, weakly positive correlation between, $\mathrm{Mn} / \mathrm{Mg}, \mathrm{Zn} / \mathrm{Al}, \mathrm{Ca} / \mathrm{Fe}, \mathrm{Mn} / \mathrm{Fe}, \mathrm{Mg} / \mathrm{Ca}, \mathrm{Zn} / \mathrm{Cr}$, $\mathrm{Zn} / \mathrm{Ni}$, weakly negative correlation between $\mathrm{Cr} / \mathrm{Ca}, \mathrm{Ni} / \mathrm{Ca}$, and no correlation between $\mathrm{Zn} / \mathrm{Mn}$, $\mathrm{Cu} / \mathrm{Mn}$, and $\mathrm{Al} / \mathrm{Ca}$.

The correlation coefficients between metals in $P$. reclinata reflected strongly positive correlation between $\mathrm{Zn} / \mathrm{Mn}, \mathrm{Cr} / \mathrm{Ni}, \mathrm{Cr} / \mathrm{Mg}, \mathrm{Cu} / \mathrm{Mn}, \mathrm{Ni} / \mathrm{Mg}, \mathrm{Zn} / \mathrm{Ca}, \mathrm{Zn} / \mathrm{Fe}, \mathrm{Cu} / \mathrm{Ca}, \mathrm{Ni} / \mathrm{Al}, \mathrm{Mn} / \mathrm{Ca}$, $\mathrm{Mg} / \mathrm{Al}, \mathrm{Al} / \mathrm{Fe}, \mathrm{Cr} / \mathrm{Al}, \mathrm{Ca} / \mathrm{Fe}$ and strongly negative correlation between $\mathrm{Cr} / \mathrm{Cu}, \mathrm{Cu} / \mathrm{Ni}, \mathrm{Cu} / \mathrm{Mg}$, moderately positive correlation between $\mathrm{Zn} / \mathrm{Cu}, \mathrm{Mn} / \mathrm{Fe}$, and moderately negative correlation between $\mathrm{Cr} / \mathrm{Mn}$, weakly positive correlation between, $\mathrm{Zn} / \mathrm{Al}, \mathrm{Cu} / \mathrm{Fe}, \mathrm{Ni} / \mathrm{Fe}, \mathrm{Cr} / \mathrm{Fe}, \mathrm{Mg} / \mathrm{Fe}$, $\mathrm{Al} / \mathrm{Ca}$, weakly negative correlation between $\mathrm{Mn} / \mathrm{Mg}, \mathrm{Ni} / \mathrm{Mn}, \mathrm{Ni} / \mathrm{Ca}, \mathrm{Mg} / \mathrm{Ca}, \mathrm{Cr} / \mathrm{Ca}, \mathrm{Cu} / \mathrm{Al}$, and no correlation between $\mathrm{Zn} / \mathrm{Cr}, \mathrm{Zn} / \mathrm{Ni}, \mathrm{Mn} / \mathrm{Al}$ and $\mathrm{Zn} / \mathrm{Mg}$.

The correlation coefficients between metals in $O$. africana reflected strongly positive correlation between $\mathrm{Zn} / \mathrm{Fe}, \mathrm{Cr} / \mathrm{Mg}, \mathrm{Cr} / \mathrm{Ni}, \mathrm{Cu} / \mathrm{Fe}, \mathrm{Mn} / \mathrm{Ca}, \mathrm{Mg} / \mathrm{Ca}, \mathrm{Mn} / \mathrm{Al}$, strongly negative correlation between $\mathrm{Zn} / \mathrm{Mn}, \mathrm{Zn} / \mathrm{Al}, \mathrm{Cr} / \mathrm{Cu}, \mathrm{Cu} / \mathrm{Ni}, \mathrm{Ni} / \mathrm{Fe}, \mathrm{Al} / \mathrm{Fe}$, moderately positive correlation between $\mathrm{Ni} / \mathrm{Al}, \mathrm{Al} / \mathrm{Ca}, \mathrm{Zn} / \mathrm{Cu}, \mathrm{Ni} / \mathrm{Mg}$, moderately negative correlation between $\mathrm{Zn} / \mathrm{Ni}, \mathrm{Zn} / \mathrm{Ca}$, $\mathrm{Cr} / \mathrm{Ca}, \mathrm{Cu} / \mathrm{Mg}, \mathrm{Cu} / \mathrm{Al}, \mathrm{Mn} / \mathrm{Mg}, \mathrm{Cr} / \mathrm{Fe}, \mathrm{Mn} / \mathrm{Fe}$, weakly positive correlation between, $\mathrm{Zn} / \mathrm{Mg}$, $\mathrm{Cr} / \mathrm{Al}, \mathrm{Ca} / \mathrm{Fe}$, weakly negative correlation between $\mathrm{Cr} / \mathrm{Mn}$, and no correlation between $\mathrm{Zn} / \mathrm{Cr}$, $\mathrm{Cu} / \mathrm{Mn}, \mathrm{Cu} / \mathrm{Ca}, \mathrm{Ni} / \mathrm{Mn}, \mathrm{Ni} / \mathrm{Ca}, \mathrm{Mg} / \mathrm{Al}$, and $\mathrm{Mg} / \mathrm{Fe}$.

The correlation coefficients between metals in L. vulgare, P. reclinata and $O$. africana plants branch reflected strongly positive correlation between, $\mathrm{Cr} / \mathrm{Ni}, \mathrm{Cu} / \mathrm{Mg}, \mathrm{Ni} / \mathrm{Mg}, \mathrm{Mn} / \mathrm{Mg}$, $\mathrm{Cu} / \mathrm{Al}, \mathrm{Ni} / \mathrm{Al}, \mathrm{Mg} / \mathrm{Al}, \mathrm{Mn} / \mathrm{Fe}, \mathrm{Mg} / \mathrm{Fe}$ and $\mathrm{Ca} / \mathrm{Fe}$, strongly negative correlation between $\mathrm{Cr} / \mathrm{Cu}$, $\mathrm{Cu} / \mathrm{Ni}, \mathrm{Cr} / \mathrm{Mg}, \mathrm{Cr} / \mathrm{Al}$ and $\mathrm{Zn} / \mathrm{Ca}$, moderately positive correlation between $\mathrm{Zn} / \mathrm{Mn}, \mathrm{Cu} / \mathrm{Mn}$ and $\mathrm{Zn} / \mathrm{Fe}$ moderately negative correlation between $\mathrm{Cr} / \mathrm{Mn}, \mathrm{Mn} / \mathrm{Ca}$, and $\mathrm{Cr} / \mathrm{Fe}$, weakly positive correlation between, $\mathrm{Zn} / \mathrm{Ni}, \mathrm{Ni} / \mathrm{Mn}, \mathrm{Mn} / \mathrm{Al}, \mathrm{Al} / \mathrm{Ca}, \mathrm{Cu} / \mathrm{Fe}, \mathrm{Ni} / \mathrm{Fe}$ and $\mathrm{Al} / \mathrm{Fe}$ weakly negative correlation between $\mathrm{Zn} / \mathrm{Cu}, \mathrm{Zn} / \mathrm{Al}, \mathrm{Ni} / \mathrm{Ca}$ and $\mathrm{Mg} / \mathrm{Ca}$ and no correlation between $\mathrm{Zn} / \mathrm{Cr}, \mathrm{Zn} / \mathrm{Mg}$, $\mathrm{Cr} / \mathrm{Ca}$ and $\mathrm{Cu} / \mathrm{Ca}$.

\section{CONCLUSION}

The levels of the metals in the three types of traditional toothbrushes from the plants namely $L$. vulgare, $P$. reclinata and $O$. africana collected from the three sampling areas indicated that there were higher concentrations of $\mathrm{Ca}, \mathrm{Fe}$ and $\mathrm{Al}$ than the other selected metals while $\mathrm{Cr}$ and $\mathrm{Ni}$ were lower in all the three samples. The overall mean concentrations determined $(\mathrm{mg} / \mathrm{kg}$, dry weight) were in the ranges of $\mathrm{Ca}(4267-36514)>\mathrm{Fe}(131-318)>\mathrm{Al}(81.6-224)>\mathrm{Mg}(46-122)$ $>\mathrm{Zn}(27.2-175)>\mathrm{Mn}(20.1-29.0)>\mathrm{Cu}(6.6-20.3)>\mathrm{Cr}(6.7-8.9)>\mathrm{Ni}(2.6-7.9)$. The mean concentrations of $\mathrm{Ca}$ in $P$. reclinata and $O$. africana were much higher as compared to the concentrations of $\mathrm{Ca}$ in $L$. vulgare, and the concentrations of $\mathrm{Zn}$ in L. vulgare was higher than the concentrations of $\mathrm{Zn}$ in $P$. reclinata and $O$. africana, the concentrations of $\mathrm{Mg}$ in L. vulgare and $O$. africana were higher than the concentrations of $\mathrm{Mg}$ in $P$. reclinata. But the concentrations of other metals were almost comparable. The toxic metals $\mathrm{Pb}$ and $\mathrm{Cd}$ were not 
detected in any of the three traditional toothbrushes studied. Therefore, the three traditional toothbrushes are safe for human use.

\section{ACKNOWLEDGMENTS}

The authors express their gratitude to the Department of Chemistry, Addis Ababa University, Ethiopia for providing the laboratory facilities. Yared Fikadu Mulualem is thankful to Addis Ababa Educational Bureau, Ethiopia for sponsoring his study.

\section{REFERENCES}

1. World Health Organization. International statistical classification of diseases and related health problems, 10th revision, 5th ed., World Health Organization: Geneva; 2016.

2. Bone, K. Phytotherapy for periodontal disease and improved oral hygiene. Townsend Letter for Doctors and Patients 2005, 263, 38-41.

3. Kassu, A.; Dagne, E.; Abate, D.; Castro, A.; Van, B.W. Ethnomedical aspects of the commonly used toothbrush sticks in Ethiopia. East Afr. Med. J. 1999, 76, 651-653.

4. Entele, W.; Chandravanshi, B.S. Metal contents in traditional chewing sticks commonly used in Ethiopia: A comparative analysis. Chem. Int. 2021, 7, 163-171.

5. Bailey, L.H. Manual of Cultivated Plants, Rev. ed., Macmillan: U.K.; 1949.

6. Govaerts, R.H.A.; Faden, R.B. World Checklist of Selected Plant Families, Royal Botanic Gardens: Kew; 2013.

7. Long, H.S.; Tilney, P.M.; Van Wyk, B.E. The ethnobotany and pharmacognosy of Olea europaea subsp. africana (Oleaceae). South Afr. J. Bot. 2010, 76, 324-331.

8. Nilsson, S. A survey of the pollen morphology of Olea with particular reference to Olea europaea Sens. Lat. Kew Bull. 1988, 43, 303-315.

9. Stolarczyk, M.; Naruszewicz, M.; Kiss, A.K. Extracts from E. pilobium sp. herbs induce apoptosis in human hormone-dependent prostate cancer cells by activating the mitochondrial pathway. J. Pharm. Pharmacol. 2013, 65, 1044-1054.

10. Somova, L.I.; Shode, F.O.; Ramnanan, P.; Nadar, A. Antihypertensive, antiatherosclerotic and antioxidant activity of triterpenoids isolated from Olea europaea, subspecies africana leaves. J. Ethnopharmacol. 2003, 84, 299-305.

11. Altinyay, Ç.; Güvenç, A.; Altun, M.L. Antioxidant activities of Oleuropein and the aqueous extracts of Olea Europaea L. varieties growing in Turkey. Turk. J. Pharm. Sci. 2011, 8, 2330

12. Lins, P.G.; Pugine, S.M.P.; Scatolini, A.M.; de Melo, M.P. In vitro antioxidant activity of olive leaf extract (Olea europaea L.) and its protective effect on oxidative damage in human erythrocytes. Heliyon 2018, 4, e00805.

13. Al-Khalil, S. A survey of plants used in Jordanian traditional medicine. Int. J. Pharmacogn. 1995, 33, 317-323.

14. Bellakhdar, J.; Claisse, R.; Fleurentin, J. and Younos, C. Repertory of standard herbal drugs in the Moroccan pharmacopoea. J. Ethnopharmacol. 1991, 35, 123-143.

15. Kokwaro, J.O. Medicinal Plants of East Africa, University of Nairobi Press: Nairobi; 2009.

16. Wu, C.D.; Darout, I.A.; Skaug, N. Chewing sticks: timeless natural toothbrushes for oral cleansing. J. Periodontal Res. 2001, 36, 275-284.

17. Al-hebshi, N.; Al-haroni, M. and Skaug, N. In vitro antimicrobial and resistance-modifying activities of aqueous crude khat extracts against oral microorganisms. Arch. Oral Biol. 2006, 51, 183-188.

18. Carvalho, M.L.; Santiago, S.; Nunes, M.L. Assessment of the essential element and heavy metal content of edible fish muscle. Anal. Bioanal. Chem. 2005, 382, 426-432. 
19. Quevauviller, P. Quality Assurance in Environmental Monitoring. Wiley-VCH Verlag GmbH: Germany; 1995.

20. Debebe, A.; Chandravanshi, B.S.; Wondimu, T. Metallic nutrients in enset (Ensete ventricosum) corm cultivated in Wolliso and Wolkite towns in Ethiopia. SINET: Ethiop. J. Sci. 2012, 35, 71-80.

21. Dubale, A.A.; Chandravanshi, B.S.; Gebremariam, K.F. Levels of major and trace metals in the leaves and infusions of Croton macrostachyus. Bull. Chem. Soc. Ethiop. 2015, 29, 11-26.

22. Abdella, A.; Chandravanshi, B.S.; Yohannes, W. Levels of selected metals in coriander (Coriandrum sativum L.) leaves cultivated in four different areas of Ethiopia. Chem. Int. 2018, 4, 189-197.

23. Admasu, S.; Chandravanshi, B.S.; Yohannes, W. Levels of selected metals in the leaves of Ruta chalepensis L. (Rue) collected from four different areas of Ethiopia. Bull. Chem. Soc. Ethiop. 2018, 32, 185-197.

24. Gebregewergis, A.; Chandravanshi, B.S.; Redi-Abshiro, M. Levels of selected metals in teff grain samples collected from three different areas of Ethiopia by using microwave plasmaatomic emission spectroscopy. Bull. Chem. Soc. Ethiop. 2020, 34, 449-462.

25. Jemaneh, D.; Chandravanshi, B.S. Mineral contents of Ethiopian red and green apple fruits: A comparison with WHO/FAO standards. Chem. Int. 2021, 7, 112-122.

26. Pawlos, Z.; Chandravanshi, B.S.; Yohannes, W.; Embiale, A. Levels of selected metals in Ficus sur Forssk fruit and soil of the plant grown in different parts of Ethiopia. SINET: Ethiop. J. Sci. 2021, 44, 1-12.

27. Gebre, A.; Chandravanshi, B.S. Levels of essential and non-essential metals in Rhamnus prinoides (Gesho) cultivated in Ethiopia. Bull. Chem. Soc. Ethiop. 2012, 26, 329-342.

28. Wagesho, Y.; Chandravanshi, B.S. Levels of essential and non-essential metals in ginger (Zingiber officinale) cultivated in Ethiopia. Springer Plus 2015, 4, 107.

29. Taha, K.K.; Al Ghtani, F.M. Determination of the elemental contents of date palm (Phoenix dactylifera L.) from Kharj Saudi Arabia. World Sci. News 2015, 6, 125-135.

30. Vella, A.; Attard, E. Analysis of heavy metal content in conventional and herbal toothpastes available at Maltese pharmacies. Cosmetics 2019, 6, 28.

31. Orisakwe, O.E.; Okolo, K.O.; Igweze, Z.N.; Ajaezi, G.C.; Udowelle, N.A. Potential hazards of toxic metals found in toothpastes commonly used in Nigeria. Roczniki Państwowego Zakładu Higieny 2016, 67(2), 197-204.

32. Rao, R.N. and Rao, T.N. Determination of heavy metals in toothpastes containing tin as an active ingredient. Indian J. Chem. Technol. 2014, 21, 238-243.

33. European Commission. Regulation (EC) No 1881/2006 of 19 December 2006 on Setting Maximum Levels for Certain Contaminants in Foodstuffs. 2006. Official J. Eur. Union 2006, 364, 5-24.

34. Codex Alimentarius Commission. Joint FAO/WHO Food Standards Programme, Codex committee on contaminants in foods. Fifth Session, The Hague, The Netherlands, 21-25 March 2011.

35. Chan, E. Health Canada Published Guidelines on Heavy Metal Impurities in Cosmetics. Sparkle Volume 632. 2012. Available online: http://www.intertek.co.th/uploadedFiles/Intertek/Divisions/Consumer Goods/

36. Hepp, N.; Mindak, W.R.; Gasper, J.W.; Thompson, C.B.; Barrows, J. Survey of cosmetics for arsenic, cadmium, chromium, cobalt, lead, mercury, and nickel content. J. Cosmet. Sci. 2014, 65, 125-145.

37. Miller, J.N.; Miller, J.C. Statistics and Chemometrics for Analytical Chemistry, 5th ed., Pearson Practice Hall: England; 2005. 